\title{
Application of cluster models in forecasting housing construction economic potential in the region
}

\author{
Victoria Sievka ${ }^{1}$, Igor Shevchuk $^{2}$, Aleksey Stepanov, ${ }^{3, *}$, Oksana Tykhankina $^{4}$ \\ ${ }^{1}$ Academy of Civil Engineering and Architecture, Derzhavina str., 2, 286123, Donetsk, Ukraine \\ ${ }^{2}$ Sevastopol Institute (Branch) of Plekhanov Russian University of Economics, Vakulenchuka Str., \\ 29-4, Sevastopol, Russia \\ ${ }^{3}$ Plekhanov Russian University of Economics, Stremyanny lane, 36, Moscow, 117997, Russia \\ ${ }^{4}$ Academy of Civil Engineering and Architecture, Artema str., 138/10, 283110, Donetsk, Ukraine
}

\begin{abstract}
The article introduces the first econometric modeling of the needs in new housing construction, reconstruction, capital repairs and finishing of uncompleted construction objects in the region on the basis of cluster models. Forecasting diagrams of gaps between the existing economic potential of housing construction and a normative need in sector housing as well as the need in introducing sector housing to reach mean European standards of housing are plotted.
\end{abstract}

\section{Introduction}

Improvement of housing for the population in the region is an important task for social policy. Usage of only new housing development stimulation for this would be incorrect without the necessary emphasis on the issues of unfinished housing completion, reconstruction of the old housing and its repair. The forecast of the demand on these sectors allows us to determine the regional economic potential of housing and to develop measures for its reproduction and realization.

This paper introduces the model of housing construction economic potential identification and forecast which accounts for the sector approach and can be implemented in the following order of stages:

1. The graphic model of the current economic potential "distance" from the normative one throughout Ukrainian regions has been built. The existing economic potential reflects the size of the general residential space introduced during the last 10 years in a certain region adjusted to impact indexes reflecting the perspectives of the building material and technical basis development, land matters, industry staff assistance, state regulation and financial aspects of relations at the housing building market.

\footnotetext{
* Corresponding author: v.g.sevka@donnasa.ru
} 
The weight of the impact factor on the normative economic potential has been calculated. Mean values of impact factors in all regions (27 determined) have been identified according to the formula (1):

$$
\overline{x_{i}^{(n)}}=\frac{1}{27} \sum_{j=1}^{27} x_{i j}^{(n)}, i=\overline{1,14}
$$

where $\overline{x_{i}^{(n)}}$ is the factor values $x_{i j}^{(n)}$ that correspond to all regions under research.

As soon as mean values for every factor (14 determined) have been identified, the weight of the impact factor mean value has been calculated according to the formula (2):

$$
\mathrm{w}_{\mathrm{i}}^{(\mathrm{n})}=\frac{\overline{\mathrm{x}_{\mathrm{i}}^{(\mathrm{n})}}}{\sum_{\mathrm{i}=1}^{14} \overline{\mathrm{x}_{\mathrm{i}}^{(\mathrm{n})}}}, \mathrm{i}=\overline{1 ; 14}
$$

The sum of the weights defined should equal to one (3):

$$
\sum_{i=1}^{14} w_{i}^{(n)}=1
$$

The weight of the impact factor on the current economic potential has been calculated. For these mean values of each impact factor weights for all regions have been identified according to the formula (4):

$$
\overline{\mathrm{x}_{\mathrm{i}}^{(\mathrm{D})}}=\frac{1}{27} \sum_{\mathrm{j}=1}^{27} \mathrm{x}_{\mathrm{ij}}^{(\mathrm{D})}, \mathrm{i}=\overline{1,14}
$$

where $\overline{\mathrm{x}_{\mathrm{i}}^{(\mathrm{D})}}$ are factor values $\mathrm{x}_{\mathrm{ij}}^{(\mathrm{D})}$, which correspond to all regions.

As soon as mean values for every impact factor have been identified, the weight of the impact factor mean value has been calculated according to the formula (4):

$$
\mathrm{w}_{\mathrm{i}}^{(\mathrm{D})}=\frac{\overline{\mathrm{x}_{\mathrm{i}}^{(\mathrm{D})}}}{\sum_{\mathrm{i}=1}^{14} \overline{\mathrm{x}_{\mathrm{i}}^{(\mathrm{D})}}}, \mathrm{i}=\overline{1 ; 14}
$$

The sum of the weights defined should equal to one.

2. Polygon corresponding to the real economic potential has been compared to the polygon corresponding to the normative (or desired in regions) one to identify similarities between these polygons and to make sure there is no disproportion in the real economic potential in all regions. The normative economic potential reflects the calculation value of the need in the housing of a certain sector which should be introduced to reach normative housing provision. The value of $21 \mathrm{sqm}$. per a person has been used as a standard. The desired potential reflects the move to the mean European norms in housing provision. The value of $35.2 \mathrm{sqm}$ per a person has been used as a standard. Disproportions in statistical approaches for accounting housing provision in Russia have been identified. For its calculation the category "residential area" is used in Russia, "total residential area" - in Ukraine and "actual residential area" - in European countries.

In the article it is offered to calculate the desired economic potential of the housing construction based on the actual residential area. The results of the corresponding calculations are introduced.

3. If the polygon corresponding to the normative economic potential is similar to the one corresponding to the real economic potential, managerial decisions directed to the gradual approach of the impact factors weight corresponding to the normative economic potential to the real economic potential weights are taken into use. Hence, it is necessary to keep to the correlation between the weights of the real economic potential.

4. If the polygon corresponding to the normative economic potential is not similar to the one corresponding to the real economic potential, the decision to eliminate disproportion is 
taken, and then managerial decisions directed to form economic potential of housing construction in a certain sector are made.

It is worth mentioning that indexes worked out by the authors of the article introduce tendencies to change housing construction in general, that is why, they should be used in new construction, reconstruction, completion of the building and capital repairs of the housing fund.

\section{Theoretical, Informational and Empirical, and Methodological Grounds of the Research}

The necessity of revision of approaches to housing projects planning is stated in the publications of leading scientists in this field (Bolotin et al. 2014; Bolotin et al. 2011; Ptukhina 2011; Amosha et al. 2010; Isayenko 2011; Karlova 2013; Mantsevich 2007; Orlovska 2014 and others).

Calculations and economic projections are based on the official statistic data (The statistical Bulletin "Housing and the number of provided apartments in Ukraine in 2012" 2013; The statistical Bulletin "Acceptance into operation of housing in Ukraine in 2012" 2013; The statistical Bulletin "The state of the buildings and facilities of unfinished construction in Ukraine as of January 1, 2013" 2013; The statistical publication "Regions of Ukraine 2012" 2012; Housing statistics 2014; Housing statistics in the European Union 2010; The order of the State Committee of construction, architecture and housing policy of Ukraine "On approval of the Single classification of residential buildings depending on the quality of available housing and engineering equipment" 1998).

The most thorough work has been done by the team in determining the potential of reconstruction, refurbishment and completion of unfinished housing (Sievka et al. 2013).

To calculate the normative economic potential of the reconstruction or capital repair, it is necessary to take into account regulations on the procedure of the identification of the cost of reconstruction or substitution of land amelioration, housings, low story buildings and structures (The law of Ukraine "On prevention of influence of world financial crisis on development of construction branch and housing construction" 2009) that recommend to evaluate the cost of building and renewal by means of reconstruction and capital repairs on the basis of the existing analogue objects.

To evaluate the potential of the reconstruction according to form factors it is reasonable to use indexes of the work cost and characteristics of the constructive elements functional analogues and work types according to eight sections: residential and countryside housings, basement, cellars and swimming pools; superstructures, extensions, garden cottages, industrial and domestic structures, buildings elements and separate constructions, the cost of construction elements repairs and types of work.

However, intended function statistical accounting of separate buildings hasn't been done. On the basis of housing rating depending on the building type (Housing code of Ukrainian SSR 1983) and its working life the need in reconstruction and capital repairs of housing in all regions has been differentiated.

Table 1. Conditions for the calculation of the demand for reconstruction and capital repairs regulatory values in all regions.

\begin{tabular}{|c|c|c|c|c|}
\hline $\begin{array}{c}\text { Housing } \\
\text { class }\end{array}$ & Working life & $\begin{array}{c}\text { Frequency of } \\
\text { capital repairs, } \\
\text { years }\end{array}$ & $\begin{array}{c}\text { Total amount of } \\
\text { housings in } \\
\text { Ukraine }\end{array}$ & $\begin{array}{c}\text { \% of the total } \\
\text { amount of } \\
\text { housings }\end{array}$ \\
\hline 1 & 150 & 75 & 77007 & 0.8 \\
\hline 2 & 125 & 60 & 285326 & 2.8 \\
\hline 3 & 100 & 50 & 758148 & 7.5 \\
\hline
\end{tabular}




\begin{tabular}{|c|c|c|c|c|}
\hline 4 & 100 & 50 & 2787344 & 27.4 \\
\hline 5 & 70 & no & 3250099 & 32.0 \\
\hline 6 & 50 & no & 3001712 & 29.5 \\
\hline Total & & & 10159636 & 100.0 \\
\hline
\end{tabular}

Such approach has statistical and normative basis, though it needs to be supplemented with the research data for assessment. Thus, only $3.6 \%$ of housing have the working life for more than 250 years. These are housings built in 1888-1913. 34.9\% of housing have the expected life for 100 years and were built in 1913-1943; 32\% - for 70 years and were built in $1943-1963 ; 29.5 \%$ - for 50 years and were built in 1963 .

Accordingly, for all housings taken into use before 1963 the working life is over. Though capital repairs could prolong their term. Thus, according to normative terms it is suggested to set the need for reconstruction of the housing built before 1960 and for capital repairs of the housing built in 1960-1990. This will correspond to a half of the maximum term of the capital repairs (50 years). Taking into consideration the researches in reconstruction and capital repairs done during the period analyzed, it is recommended to use the decreasing coefficient calculated as the difference between a unity and an average growth (decrease) of the reconstruction or capital repairs.

It is reasonable to complete this approach with the evaluation of housing according to their age.

Analyses of the normative requirements to the reconstruction of uncompleted buildings signifies of no restrictions concerning the year of building and the stage of the housing availability. Possibility for further construction and recommendations to its cost are determined on the basis of the technical expertise of the housing and are regulated by the Law of Ukraine "On the regulation of the city planning activity". To calculate the inventory cost it is necessary to use the directions on the order of technical property inventory.

An attempt to standardize approaches to finishing and taking into use uncompleted housing was done in 2008 on the basis of the Law of Ukraine "On the prevention of the world financial crisis influence on the development of the building industry and housing" (The order of the state property Fund of Ukraine and State Committee of Ukraine on housing and communal services "On approval of the Procedure for determining the cost of reproduction or replacement of land improvements, buildings, buildings and constructions of low-rise housing construction" 2005) including buying out of uncompleted housing for the state funds.

Restrictions towards state funding by means of housing buy outs depended on the level of their readiness, thus, restriction to funding was used in 2009 to housings finished by $70 \%$; in 2010 - more than $50 \%$.

The level of readiness is identified by the Interagency Committee considering proposals to form the list of housing that require funding to finish building or to buy dwelling in them. The work of committee is connected with certain housings and there is no general information as for managing uncompleted building in the regions. Such approach can be considered temporary and there is no complexity in the management of this process by the state.

Thus, to calculate the normative demand in finishing uncompleted building it is suggested to apply factual data of the general area of such buildings during a year and to consider the tempo of such area growth.

It is also reasonable to create on the regional level a list of building objects according to the year the building started, the stages of their readiness, differentiation of housings being built, finished with the introduction of problems causing the end of building and the results of building inventory.

Therefore, it is reasonable to make up a corresponding regional program of finishing housing in the term of 10 years. Such approach will allow arrangement of measures to 
finish building, to find state, local budget or investor funding sources. Addition of the demands in social and available dwelling for regional needs to the program will make for the use of uncompleted building as the basis for social programs implementation with the lowest budget expenditures.

To calculate the desired housing economic potential it is necessary to take into account European norms of housing provision. For this evaluation of the approaches to registration and housing fund movement, housing cost and its affordability, housing provision per resident as well as constitute social indicators in housing provision has been done. Different methodologies to register statistic data of housing provision used in Ukraine and other European countries do not allow to make conclusions concerning the efficiency of housing policy. Housing provision in Ukraine is calculated depending on the total space (The statistical Bulletin "Housing and the number of provided apartments in Ukraine in 2012" 2013) while European approaches take into account actual residential space per person (The order of the State Committee of construction, architecture and housing policy of Ukraine "On approval of the Single classification of residential buildings depending on the quality of available housing and engineering equipment" 1998) or total residential space of the residential fund per a housing and acceptable dwelling per a housing. Differences in rating total space (21 sqm per person and additionally $10 \mathrm{sqm}$ per family) (Floor area: Glossary of statistical terms, part 66) and residential space (13.65 sqm per family member) (Floor area: Glossary of statistical terms, part 49) in Ukraine is explained by the assigned purpose of the process. In the first case the total space is needed for calculating the cost of residential, for privatization and registration. In the second - as a sanitary norm of the state housing policy to provide quality housing conditions. The total space of the housing is determined as a sum of residential area and service area space. Stairs, elevators, halls, entries, common corridors, vestibules, galleries, nonresidential housing areas are not included into the total space. Balconies, recessed balconies, terraces, storerooms are accounted with the decreasing coefficient. Residential space is defined as the sum of all residential spaces without built-in wardrobes. Kitchen area, corridors, bathroom space, storerooms, built-in wardrobes and other service areas as well as the space of residential rooms changed into nonresidential ones do not belong to the residential space. According to the technical norms residential and service areas, balconies, verandas and terraces should refer to the total residential area.

According to the glossary of statistical terms in European countries (The order of the Russian Federation "On approval of the Instruction on carrying out accounting of the housing Fund in the Russian Federation" 1998) the total space of the residential housing is equal to the sum of each floor space measured according to the external space of walls including the space of hallways, basements, lift shafts and other service areas except balconies. It means that statistical total space in Ukraine is lowered and needs to be review in comparison to European data.

Hence, in Europe two terms are used to measure the residential space - "rentable residential space" measured according to the internal wall parameters excluding basement areas inappropriate for residential attics and common areas and "residential space" as a sum of all residential room spaces. Statistic reports in European countries are filled on the basis of the marker "rentable residential space" and in Ukraine "residential area".

Total residential area in Russia is calculated similarly to Ukrainian parameters and is identified as the sum of residential room spaces, but in official statistical accounting the term "rentable residential space" is used which corresponds to European standards (Beer Stafford 1998, part 3.34).

Thus, in comparison with European markers and further calculation of the desired economical potential of the housing it is necessary to change the marker "residential area" into "rentable residential area". To identify rentable residential area in Ukraine, the 
residential area should be increased for the space of the kitchen area, lavatory, bathroom area, internal corridors. Since accounting of this information in statistics is not done, average percentage value regulated by SBC B.2.2-15-2005 "Housing. Fundamental principles" in providing comfort to one-family housings and dwellings in block of flats funds. In this paper minimal room spaces $(22.2 \mathrm{sqm})$ to calculate the space of the medium flat residential area, minimal kitchen areas, lavatory and bathroom areas $(11.3 \mathrm{sqm})$ corresponding to $51 \%$ of the minimal residential area are used. Thus, to recalculate the residential area into rentable one, the real residential area in regions and in Ukraine in general should be increased by $51 \%$.

It is worth mentioning that the rate of the residential area to the total one in 2012 made $63.2 \%$, it means that minimal comfort standards introduced in the state building norms are not kept to on average in Ukraine, the space of lavatories, bathrooms and kitchens is 12.2 times lower.

Thus, to reach middle European rates it is necessary to increase rentable residential space provision in Ukraine on average by $12.3 \mathrm{sqm}$. However, it is worth highlighting different time periods of the statistical examination of housing provision in European countries and differences in accounting rentable residential space. Thus, in Austria only main residence is taken into account, in the Czech Republic - only permanent dwelling, in the UK - vacant non inhabited dwelling is not accounted. Moreover, in Finland in early 1960s rentable residential space per person was a little bit over 14 sqm and till 1992 it doubled and equaled to 32 sqm. Accordingly, in 2013 these indicators can be increased taking into account the tendency to population decrease.

Hence, at the real tempos of new building to reach normative provision of population with the total residential space can be possible in 36.9 years and the desired one - in 61.6 years if the population size is the same.

To identify impact factors on the possibility of the real potential to reach the normative level and the desired (European) one the approach based on creating cluster model has been used.

To do this variables $Y_{i}, i=\overline{1,27}$ corresponding to the calculated real potential in each out of 27 regions in Ukraine (21 regions, AR of Crimea, Kyiv, Sevastopol), such as AR of Crimea - Y1,..., Sevastopol - Y27 have been introduced.

Each region is characterized by the index values divided into two groups "possibility" and "ability".

Let's indicate indexes "possibility" and "ability" using variables $X_{i}, i=\overline{1,14}$ : Index of the dwelling queue increase in a certain housing fund during a year X1, Index of state housing regulation and approval - X14. Let's identify the weight of every index (Ii) For this let's divide the value of every index by the sum of 14 indexes indicated (5):

$$
\begin{aligned}
& \mathrm{I}_{1}=\frac{\mathrm{I}_{\mathrm{nch}}}{\mathrm{I}_{\mathrm{nch}}+\cdots+\mathrm{I}_{\mathrm{drrb}}} ; \\
& \mathrm{I}_{14}=\frac{\mathrm{I}_{\mathrm{drrb}}}{\mathrm{I}_{\text {nch }}+\cdots+\mathrm{I}_{\mathrm{drrb}}}
\end{aligned}
$$

Let's introduce variables $x_{i}^{D}, i=\overline{1,14}$ the meaning of which equals to the multiplication of the "weight" Ii by the value of the corresponding housing potential in the region (6):

$$
\begin{aligned}
& \left(x_{i}^{D}\right)^{j}=I_{i}\left(Z P_{n b d i s}\right)_{j} ; \\
& i=\overline{1 ; 14} ; j=\overline{1 ; 27}
\end{aligned}
$$

Thus, each region can be introduced by the appropriate point in the factor space $\mathrm{Yj}$, which has 14 coordinates, namely (7): 


$$
Y_{j}=\left(\left(x_{1}^{D}\right)^{j},\left(x_{2}^{D}\right)^{j}, \ldots,\left(x_{14}^{D}\right)^{j}\right), j=\overline{1,27}
$$

Let's analyze in the factor space the set consisting of 27 points: Y1, Y2, .., Y27 and evaluate the diameter of this point.

The base data are presented in Table 2 .

Table 2. Base data of the factor space for the set "diameter" evaluation.

\begin{tabular}{|c|c|c|c|c|}
\hline$Y_{j}^{D} \quad x_{i}^{D}$ & $\mathrm{x}_{1}^{\mathrm{D}}$ & $\mathrm{x}_{2}^{\mathrm{D}}$ & $\ldots$ & $\mathrm{x}_{14}^{\mathrm{D}}$ \\
\hline $\mathrm{Y}_{1}^{\mathrm{D}}$ & $\left(x_{1}^{\mathrm{D}}\right)^{1}$ & $\left(x_{2}^{\mathrm{D}}\right)^{1}$ & $\ldots$ & $\left(\mathrm{x}_{14}^{\mathrm{D}}\right)^{1}$ \\
\hline $\mathrm{Y}_{2}^{\mathrm{D}}$ & $\left(x_{1}^{D}\right)^{2}$ & $\left(\mathrm{x}_{2}^{\mathrm{D}}\right)^{2}$ & $\ldots$ & $\left(\mathrm{x}_{14}^{\mathrm{D}}\right)^{2}$ \\
\hline$\ldots$ & $\ldots$ & $\ldots$ & $\ldots$ & $\ldots$ \\
\hline$Y_{27}^{D}$ & $\left(x_{1}^{D}\right)^{27}$ & $\left(x_{2}^{D}\right)^{27}$ & $\ldots$ & $\left(x_{14}^{D}\right)^{27}$ \\
\hline
\end{tabular}

Let's take point $\mathrm{Y}^{*}$ of the set the coordinates of which equal to variable mean values of each coordinate as the center of the set (8), namely:

$$
\mathrm{Y}^{*}=\left(\mathrm{x}_{1}^{*}, \mathrm{x}_{2}^{*}, \ldots, \mathrm{x}_{27}^{*}\right)
$$

where $x_{i}^{*}=\frac{1}{27} \sum_{1}^{27}\left(x_{i}^{D}\right)^{j}, i=\overline{1 ; 14} ; j=\overline{1 ; 27}$.

Let's find the distances $(\mathrm{d})$ between each point $\mathrm{Yj}$ from point $\mathrm{Y}^{*}$ according to the standard formula in Euclidean space (9):

$$
\begin{gathered}
d_{j}^{D}=\rho\left(Y_{j}^{D}, Y^{*}\right)=\sqrt{\sum_{1}^{14}\left(\left(x_{i}^{D}\right)^{j}-x_{i}^{*}\right)^{2}}, \\
i=\overline{1 ; 14} ; j=\overline{1 ; 27}
\end{gathered}
$$

$\mathrm{d}_{1}^{\mathrm{D}}, \mathrm{d}_{2}^{\mathrm{D}}, \ldots, \mathrm{d}_{27}^{\mathrm{D}}$ is received in the sum of 27 distance values.

The "diameter" $d_{Y}^{D}$ of the set, that consists of the points $Y_{1}^{D}, Y_{2}^{D}, \ldots, Y_{27}^{D}$ has the maximum valued $\mathrm{d}_{1}^{\mathrm{D}}, \mathrm{d}_{2}^{\mathrm{D}}, \ldots, \mathrm{d}_{27}^{\mathrm{D}}$, namely:

$$
d_{Y}^{D}=\max \left\{d_{j}^{D}, j=\overline{1 ; 27}\right\}
$$

Let's study the same points $\mathrm{Y}_{1}^{\mathrm{D}}, \mathrm{Y}_{2}^{\mathrm{D}}, \ldots, \mathrm{Y}_{27}^{\mathrm{D}}$ but as variable ones, $\mathrm{x}_{\mathrm{i}}, \mathrm{i}=\overline{1,14}$ and multiply the "weight" Ii by the value of the corresponding normative economical potential of the housing in the region (11), namely:

$$
\begin{gathered}
\left(x_{i}^{H}\right)^{j}=I_{i}\left(Z P_{\text {nbnorm }}\right)_{j} ; \\
i=\overline{1 ; 14} ; j=\overline{1 ; 27}
\end{gathered}
$$

Thus, each region can be represented by a corresponding point in the indicated factor space indicated which has 14 coordinates. But this point will characterize the normative housing economical potential in the region taking into account indexes "ability" and "possibility". On analogy to the previous algorithm the distance $d_{j}^{H}$ of the point $Y_{j}^{H}$ from the point $\mathrm{Y}^{*}$ is identified according to the formula (12):

$$
\begin{gathered}
d_{j}^{H}=\rho\left(Y_{j}^{H}, Y^{*}\right)=\sqrt{\sum_{1}^{14}\left(\left(x_{i}^{H}\right)^{j}-x_{i}^{*}\right)^{2}}, \\
i=\overline{1 ; 14} ; j=\overline{1 ; 27}
\end{gathered}
$$

As a result 27 values of distances $\mathrm{d}_{1}^{\mathrm{H}}, \mathrm{d}_{2}^{\mathrm{H}}, \ldots, \mathrm{d}_{27}^{\mathrm{H}}$ are defined:

Let's find the difference between distances $d_{j}^{H}$ and $d_{j}^{D}, j=\overline{1 ; 27}$ (13). 


$$
\Delta_{j}=d_{j}^{H}-d_{j}^{D}=\rho\left(Y_{j}^{H}, Y^{*}\right)-\rho\left(Y_{j}^{D}, Y^{*}\right), j=\overline{1 ; 27}
$$

This difference $\Delta_{\mathrm{j}}$ is an integral indicator which accounts for the value of 14 indexes as well as the normative potential and the real economic potential of housing in the region. The value $\Delta_{\mathrm{j}}$ indicates remoteness of the normative potential from the real one.

Thus, according to the segments of residential housing "new housing", "reconstruction", "completion of uncompleted housing" and "capital repairs" for every individual region it is possible to get a visible idea of the state of the real and normative potentials.

Internal set is a set that characterizes real economic potential of the chosen housing segment in the regions of Ukraine and external jogged line characterizes the normative economical potential.

Usually the area between two jogged lines characterizes divergence between potentials and regions.

Let's create a multifactor linear regressive model that describes the dependence of the distance of the set variable elements $\mathrm{Y}=\left\{\mathrm{Y}_{1}, \mathrm{Y}_{2}, \ldots, \mathrm{Y}_{27}\right\}$ each depending on the variables $\mathrm{Z}=\left\{\mathrm{Z}_{1}, \mathrm{Z}_{2}, \ldots, \mathrm{Z}_{27}\right\}$ from the appropriate set element $\mathrm{Z}=\left\{\mathrm{Z}_{1}, \mathrm{Z}_{2}, \ldots, \mathrm{Z}_{27}\right\}$. The base data are presented in Table 3 .

Table 3. Basic data for creating a multifactor model.

\begin{tabular}{|c|c|c|c|c|}
\hline$d_{j, Z} \quad x_{i}^{Y}$ & $\mathrm{x}_{1}^{\mathrm{Y}}$ & $\mathrm{x}_{2}^{\mathrm{Y}}$ & $\ldots$ & $\mathrm{x}_{14}^{\mathrm{Y}}$ \\
\hline $\mathrm{d}_{1, \mathrm{z}}$ & $\mathrm{x}_{1,1}^{\mathrm{Y}}$ & $\mathrm{x}_{1,2}^{\mathrm{Y}}$ & $\ldots$ & $\mathrm{x}_{1,14}^{\mathrm{Y}}$ \\
\hline $\mathrm{d}_{2, \mathrm{z}}$ & $\mathrm{X}_{2,1}^{\mathrm{Y}}$ & $\mathrm{x}_{2,2}^{\mathrm{Y}}$ & $\ldots$ & $\mathrm{x}_{2,14}^{\mathrm{Y}}$ \\
\hline$\ldots$ & & & $\ldots$ & \\
\hline $\mathrm{d}_{27, \mathrm{Z}}$ & $x_{27,1}^{Y}$ & $x_{27,2}^{Y}$ & $\ldots$ & $x_{27,14}^{Y}$ \\
\hline
\end{tabular}

$\mathrm{d}_{\mathrm{j}, \mathrm{Z}}$ indicates the distance of the $\mathrm{Z}$ point set $\mathrm{j}$-element-from $\mathrm{Y}$ point $\mathrm{j}$-element.

Multifactor linear regressive model is introduced in the following way (14):

$$
\mathrm{d}=\mathrm{a}_{0}+\sum_{\mathrm{i}=1}^{14} \mathrm{a}_{\mathrm{i}} \mathrm{x}_{\mathrm{i}}
$$

Coefficients of the model $a_{0}$ and $a_{i}, i=\overline{1 ; 14}$ will be evaluated according to the method of the smallest squares. For this let's get the values of the coefficients which give the minimum sum squares of differences between theoretical (modeling) values $d$ and values that are observed (calculated on the basis of the corresponding values).

The sum squares of differences is introduced in the following way:

$$
\begin{aligned}
S\left(a_{0}, a_{1}, \ldots, a_{14}\right) & =\sum_{j=1}^{27}\left(d-d_{j, Z}\right)^{2} \\
& =\sum_{j=1}^{27}\left(a_{0}+a_{1} x_{j, 1}^{Y}+\cdots+a_{14} x_{j, 14}^{Y}-d_{j, Z}\right)^{2}=\sum_{j=1}^{27}\left(a_{0}+\sum_{j=1}^{14} a_{i} x_{j i}^{Y}-d_{j, Z}\right)^{2}
\end{aligned}
$$

Let's define the minimum of function $S=S\left(a_{0}, a_{1}, \ldots, a_{14}\right)$.

Let's calculate partial derivatives for this: 


$$
\begin{gathered}
\frac{\partial S}{\partial \mathrm{a}_{0}}=\frac{\partial}{\partial \mathrm{a}_{0}} \sum_{j=1}^{27}\left(\mathrm{a}_{0}+\mathrm{a}_{1} \mathrm{x}_{\mathrm{j}, 1}^{\mathrm{Y}}+\cdots+\mathrm{a}_{14} \mathrm{x}_{\mathrm{j}, 14}^{\mathrm{Y}}-\mathrm{d}_{\mathrm{j}, \mathrm{Z}}\right)^{2} \\
=2 \sum_{\mathrm{i}=1}^{27}\left(\mathrm{a}_{0}+\mathrm{a}_{1} \mathrm{x}_{\mathrm{j}, 1}^{\mathrm{Y}}+\cdots+\mathrm{a}_{14} \mathrm{x}_{\mathrm{j}, 14}^{\mathrm{Y}}-\mathrm{d}_{\mathrm{j}, \mathrm{Z}}\right) \\
\frac{\partial \mathrm{S}}{\partial \mathrm{a}_{\mathrm{k}}}=\frac{\partial}{\partial \mathrm{a}_{\mathrm{k}}} \sum_{\mathrm{j}=1}^{27}\left(\mathrm{a}_{0}+\mathrm{a}_{1} \mathrm{x}_{\mathrm{j}, 1}^{\mathrm{Y}}+\cdots+\mathrm{a}_{14} \mathrm{x}_{\mathrm{j}, 14}^{\mathrm{Y}}-\mathrm{d}_{\mathrm{j}, \mathrm{Z}}\right)^{2} \\
=2 \sum_{\mathrm{i}=1}^{27}\left(\mathrm{a}_{0}+\mathrm{a}_{1} \mathrm{x}_{\mathrm{j}, 1}^{\mathrm{Y}}+\cdots+\mathrm{a}_{14} \mathrm{x}_{\mathrm{j}, 14}^{\mathrm{Y}}-\mathrm{d}_{\mathrm{j}, \mathrm{Z}}\right) \mathrm{x}_{\mathrm{j}, \mathrm{k}}^{\mathrm{Y}} \\
\mathrm{k}=\frac{1 ; 14}{1 ;}
\end{gathered}
$$

Equaling partial derivatives calculated to the null the following system of linear equations for coefficient marks $\mathrm{a}_{0}, \mathrm{a}_{1}, \ldots, \mathrm{a}_{14}$ is obtained:

$$
\left\{\begin{array}{c}
27 a_{0}+a_{1} \sum_{j=1}^{27} x_{j, 1}^{Y}+\cdots+a_{14} \sum_{j=1}^{27} x_{j, 14}^{Y}=\sum_{j=1}^{27} d_{j, Z} \\
\sum_{j=1}^{27} x_{j, 1}^{Y} a_{0}+a_{1} \sum_{j=1}^{27}\left(x_{j, 1}^{Y}\right)^{2}+\cdots+a_{14} \sum_{j=1}^{27} x_{j, 14}^{Y} x_{j, 1}^{Y}=\sum_{j=1}^{27} d_{j, Z} x_{j, 1}^{Y} \\
\sum_{j=1}^{27} x_{j, k}^{Y} a_{0}+a_{1} \sum_{j=1}^{27} x_{j, 1}^{Y} x_{j, k}^{Y}+\cdots+a_{14} \sum_{j=1}^{27} x_{j, 14}^{Y} x_{j, k}^{Y}=\sum_{j=1}^{27} d_{j, Z} x_{j, k}^{Y} ; \\
27 \\
\sum_{j=1}^{27} x_{j, 14}^{Y} a_{0}+a_{1} \sum_{j=1}^{27} x_{j, 1}^{Y} x_{j, 14}^{Y}+\cdots+a_{14} \sum_{j=1}^{27}\left(x_{j, 14}^{Y}\right)^{2}=\sum_{j=1}^{27} d_{j, Z} x_{j, 14}^{Y} .
\end{array}\right.
$$

Let's introduce an extended coefficient matrix of this system of equations:

$$
\left(\begin{array}{cccc|c}
27 & \sum_{j=1}^{27} \mathrm{x}_{\mathrm{j}, 1}^{\mathrm{Y}} & \ldots & \sum_{\mathrm{j}=1}^{27} \mathrm{x}_{\mathrm{j}, 14}^{\mathrm{Y}} & \sum_{\mathrm{j}=1}^{27} \mathrm{~d}_{\mathrm{j}, \mathrm{Z}} \\
\sum_{\mathrm{j}=1}^{27} \mathrm{x}_{\mathrm{j}, 1}^{\mathrm{Y}} & \sum_{\mathrm{j}=1}^{27}\left(\mathrm{x}_{\mathrm{j}, 1}^{\mathrm{Y}}\right)^{2} & \cdots & \sum_{\mathrm{j}=1}^{27} \mathrm{x}_{\mathrm{j}, 14}^{\mathrm{Y}} \mathrm{x}_{\mathrm{j}, 1}^{\mathrm{Y}} & \sum_{\mathrm{j}=1}^{27} \mathrm{~d}_{\mathrm{j}, \mathrm{Z}} \mathrm{x}_{\mathrm{j}, 1}^{\mathrm{Y}} \\
\sum_{\mathrm{j}=1}^{27} \mathrm{x}_{\mathrm{j}, \mathrm{k}}^{\mathrm{Y}} & \sum_{\mathrm{j}=1}^{27} \mathrm{x}_{\mathrm{j}, 1}^{\mathrm{Y}} \mathrm{x}_{\mathrm{j}, \mathrm{k}}^{\mathrm{Y}} & \cdots & \sum_{\mathrm{j}=1}^{27} \mathrm{x}_{\mathrm{j}, 14}^{\mathrm{Y}} \mathrm{x}_{\mathrm{j}, \mathrm{k}}^{\mathrm{Y}} & \sum_{\mathrm{j}=1}^{27} \mathrm{~d}_{\mathrm{j}, \mathrm{Z}} \mathrm{x}_{\mathrm{j}, \mathrm{k}}^{\mathrm{Y}} \\
\cdots & \cdots & \cdots \\
\sum_{\mathrm{j}=1}^{27} \mathrm{x}_{\mathrm{j}, 14}^{\mathrm{Y}} & \sum_{\mathrm{j}=1}^{27} \mathrm{x}_{\mathrm{j}, 1}^{\mathrm{Y}} \mathrm{x}_{\mathrm{j}, 14}^{\mathrm{Y}} & \cdots & \sum_{\mathrm{j}=1}^{27}\left(\mathrm{x}_{\mathrm{j}, 14}^{\mathrm{Y}}\right)^{2} & \sum_{\mathrm{j}=1}^{27} \mathrm{~d}_{\mathrm{j}, \mathrm{Z}} \mathrm{x}_{\mathrm{j}, 14}^{\mathrm{Y}}
\end{array}\right)
$$

Solving the system of the equations got according to Gauss approach and changing the extended coefficient matrix of this equations system to the triangle shape, the following coefficient evaluations have been received: $\mathrm{a}_{0}{ }^{*}, \mathrm{a}_{1}{ }^{*}, \ldots, \mathrm{a}_{14}{ }^{*}$.

Let's evaluate the adequacy of this model. For this let's calculate the value of the coefficient determination $\mathrm{R}^{2}(15)$ :

$$
\mathrm{R}^{2}=1-\frac{\text { ESS }}{\text { ETT }}
$$

where ESS $=\sum_{\mathrm{j}=1}^{27}\left(\mathrm{~d}_{\mathrm{j}, 2}-\left(\mathrm{a}_{0}{ }^{*}+\mathrm{a}_{1}{ }^{*} \mathrm{X}_{\mathrm{j}, 1}^{\mathrm{Y}}+\cdots+\mathrm{a}_{14}{ }^{*} \mathrm{x}_{\mathrm{j}, 14}^{\mathrm{Y}}\right)\right)^{2}$, 


$$
\begin{gathered}
\text { ETT }=\sum_{j=1}^{27}\left(d_{j, 2}-\overline{d_{z}}\right)^{2}, \\
\overline{d_{\mathrm{z}}}=\frac{1}{27} \sum_{j=1}^{27} d_{j, z} .
\end{gathered}
$$

If the coefficient of determination has the value less than $50 \%$, the model is acceptable.

If the model built is adequate, let's range coefficient marks in the order of their increase. The indexes that correspond to the biggest values of the coefficient model have the greatest impact on the remoteness of set points $\mathrm{Y}=\left\{\mathrm{Y}_{1}, \mathrm{Y}_{2}, \ldots, \mathrm{Y}_{27}\right\}$ from the set $\mathrm{Z}=\left\{\mathrm{Z}_{1}, \mathrm{Z}_{2}, \ldots, \mathrm{Z}_{27}\right\}$ and, accordingly, they need to be effected to bring the calculated potential of the region to the normative one.

Let's build a multifactor linear model that describes dependence of the distance $d$ of the derived set element $Y=\left\{Y_{1}, Y_{2}, \ldots, Y_{27}\right\}$ on the set $W=\left\{W_{1}, W_{2}, \ldots, W_{27}\right\}$, variables $X_{1}^{Y}, X_{2}^{Y}$, $\ldots, \mathrm{X}_{14}^{\mathrm{Y}}$ where each variable $\mathrm{X}_{\mathrm{j}}^{\mathrm{Y}}$ is the product of multiplication of the corresponding index $\mathrm{x}_{\mathrm{j}}^{\mathrm{Y}}$ by the housing area taken into use in Ukraine at the research time in all regions. Then let's evaluate model coefficient values, check their adequacy, and in case of their adequacy let's range the values of model coefficients received.

\section{Results}

On the basis of the model created calculations with the Statistic package have been done. Since the corresponding set points $\mathrm{Z}$ and $\mathrm{W}$ are very close to each other evaluation of distance model coefficients between the corresponding points has been done for $\mathrm{Y}$ and $\mathrm{Z}$. Multifactor model of the average value of a new housing $Z P n b_{\text {dis }}$ is introduced in the following way (if $\mathrm{R}^{2}=0.67042991$ ):

$$
\begin{aligned}
\ln \mathrm{d}^{\mathrm{Z}}=-3.04 & +8.22 \mathrm{x}_{1}+0.01 \mathrm{x}_{2}+0.43 \mathrm{x}_{3}+2.04 \mathrm{x}_{4}+0.58 \mathrm{x}_{5}+0.50 \mathrm{x}_{6}-1.04 \mathrm{x}_{7} \\
& +2.03 \mathrm{x}_{8}-0.32 \mathrm{x}_{9}+0.34 \mathrm{x}_{10}+3.39 \mathrm{x}_{11}-0.27 \mathrm{x}_{12}-4.56 \mathrm{x}_{13} \\
& +0.17 \mathrm{x}_{14}
\end{aligned}
$$

The following multiplicative model is received:

$$
\mathrm{d}^{\mathrm{Z}}=\mathrm{e}^{-3.04+8.22 \mathrm{x}_{1}+0.01 \mathrm{x}_{2}+0.43 \mathrm{x}_{3}+2.04 \mathrm{x}_{4}+0.58 \mathrm{x}_{5}+0.50 \mathrm{x}_{6}-1.04 \mathrm{x}_{7}+}
$$

or

$$
\begin{gathered}
\mathrm{d}^{\mathrm{Z}}=\mathrm{e}^{-3.04} \mathrm{e}^{8.22 \mathrm{x}_{1}} \mathrm{e}^{0.01 \mathrm{x}_{2}} \mathrm{e}^{0.43 \mathrm{x}_{3}} \mathrm{e}^{2.04 \mathrm{x}_{4}} \mathrm{e}^{0.58 \mathrm{x}_{5}} \mathrm{e}^{0.50 \mathrm{x}_{6}} \mathrm{e}^{-1.04 \mathrm{x}_{7}} \\
\cdot \mathrm{e}^{2.03 \mathrm{x}_{8}} \mathrm{e}^{-0.32 \mathrm{x}_{9}} \mathrm{e}^{0.34 \mathrm{x}_{10}} \mathrm{e}^{3.39 \mathrm{x}_{11}} \mathrm{e}^{-0.27 \mathrm{x}_{12}} \mathrm{e}^{-4.56 \mathrm{x}_{13}} \mathrm{e}^{0.17 \mathrm{x}_{14}}
\end{gathered}
$$

The values of the coefficients calculated denote the change in distance $\mathrm{d}^{\mathrm{Z}}$ of the real potential from the normative and desired (European) ones when indexes "ability" and "possibility" have changed by xi y e a times. Symbol "+" before the coefficient a denotes the impact of factor xi on the increase of the remoteness of the real potential from the normative and desired ones. Accordingly, symbol "-_" before the coefficient a denotes the impact of factor xi change on the decrease of the remoteness of the real potential from the normative one. According to the value change calculations of the distance of the real economic potential from the normative and desired (European) ones it has been identified, that the increase of the remoteness of the real potential ( $\left.{ }^{\mathrm{Znb}} \mathrm{dis}\right)$ is greatly affected by the increase of index of dwelling queue weight on the housing fund taken into use during a year $\left(x^{1}\right)$, the growth of the increase (decrease) index of rundown and emergency housing fund $\left(\mathrm{x}^{4}\right)$, innovative activity index in building $\left(\mathrm{x}^{8}\right)$, index of in-service education in building 
$\left(\mathrm{x}^{11}\right)$. The greatest impact on the decrease of the distance between the real economic potential and the normative one according to the segment of new building has the increase of the index of the material and technical base in building $\left(\mathrm{x}^{7}\right)$, index of engineering staff training activation $\left(\mathrm{x}^{12}\right)$, index of labor supply $\left(\mathrm{x}^{13}\right)$.

Graphic image of the "remoteness" of the real and normative potentials for the average value of the new building ( ${ }^{\text {Zpnb }}$ dis) throughout the regions of Ukraine is introduced in Figure 1.

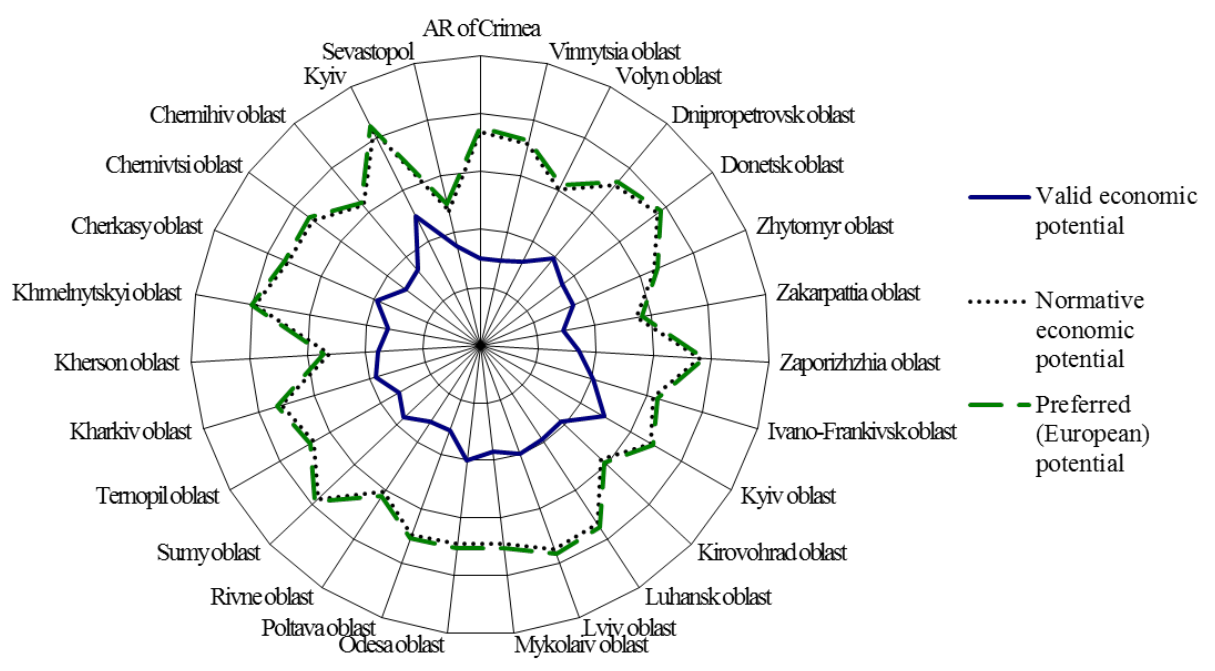

Fig. 1. Graphic model of the "distance" of the real economic potential of the new housing ( $Z P n b$ dis) from the normative and the desired ones in the regions of Ukraine.

On the basis of the multiplicative model built the potential of the housing has been calculated in the following sectors: available, social housing, elite-class housing, market multiple dwelling housing, countryside housing.

The model for the average reconstruction value ( $Z$ Prek dis) (if $\left.\mathrm{R}^{2}=0.70897460\right)$ is represented in the following way:

$$
\begin{aligned}
\ln \mathrm{d}^{\mathrm{Z}}=5.95 & +3.30 \mathrm{x}_{1}+1.29 \mathrm{x}_{2}+0.65 \mathrm{x}_{3}-1.16 \mathrm{x}_{4}+0.29 \mathrm{x}_{5}+0.31 \mathrm{x}_{6}-2.00 \mathrm{x}_{7} \\
& +1.26 \mathrm{x}_{8}-0.16 \mathrm{x}_{9}-0.02 \mathrm{x}_{10}+1.57 \mathrm{x}_{11}-0.15 \mathrm{x}_{12}-2.09 \mathrm{x}_{13} \\
& +0.06 \mathrm{x}_{14}
\end{aligned}
$$

The graphic image of the potentials remoteness in the regions for the average value of reconstruction is introduced in Figure 2. 

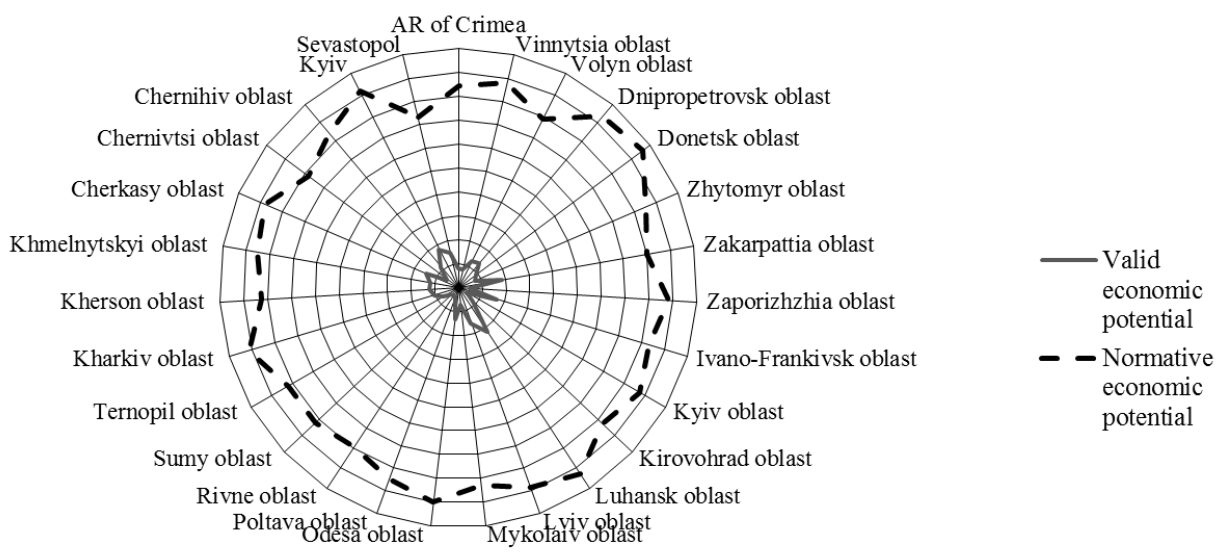

Fig. 2. The graphic model of the "distance" of the real economic potential of the average.

The model of the factor impact on the remoteness of potentials for the completion of uncompleted housing ( $Z P d o b_{\text {dis }}$ ) with the graphic image (Figure 3) and coefficients received has shown disproportion in potentials levels $\left(\mathrm{R}^{2}=0.40377544\right)$ :

$$
\begin{aligned}
\ln \mathrm{d}_{2}{ }_{2}-\operatorname{lnd}_{1} \mathrm{Y}_{1} & -969.57-149.03 \mathrm{x}_{1}+1482.75 \mathrm{x}_{2}-155.18 \mathrm{x}_{3}-88.32 \mathrm{x}_{4}+19.93 \mathrm{x}_{5} \\
& -50.88 \mathrm{x}_{6}-58.92 \mathrm{x}_{7}-277.23 \mathrm{x}_{8}+28.70 \mathrm{x}_{9}-46.85 \mathrm{x}_{10}+168.52 \mathrm{x}_{11} \\
& +33.46 \mathrm{x}_{12}+35.88 \mathrm{x}_{13}-93.13 \mathrm{x}_{14}
\end{aligned}
$$

The level of coefficients defined allows to identify the influence of factors for the potential remoteness of the potentials of the capital repairs average value ( $Z P k r$ dis) (Figure 4).
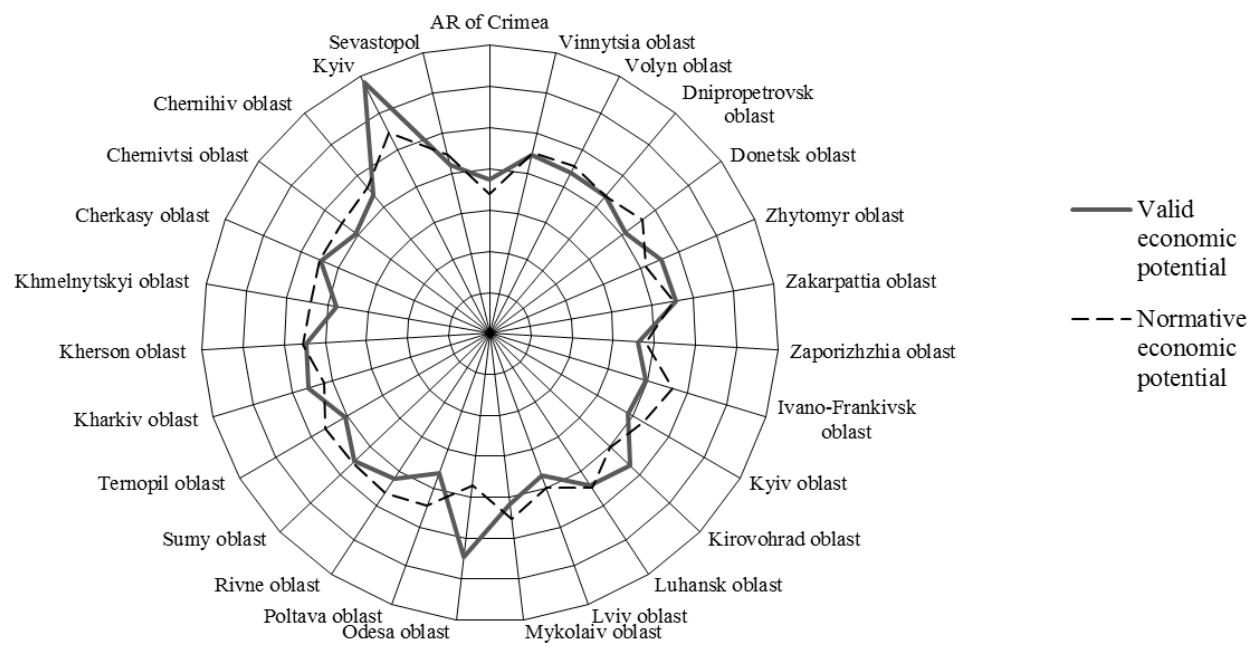

Fig. 3. The graphic model of the "distance" of the real economic potential of the average value of

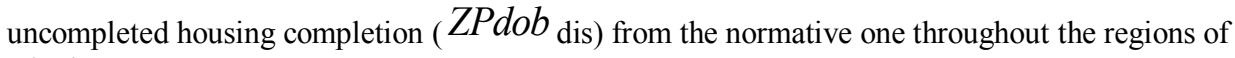
Ukraine. 


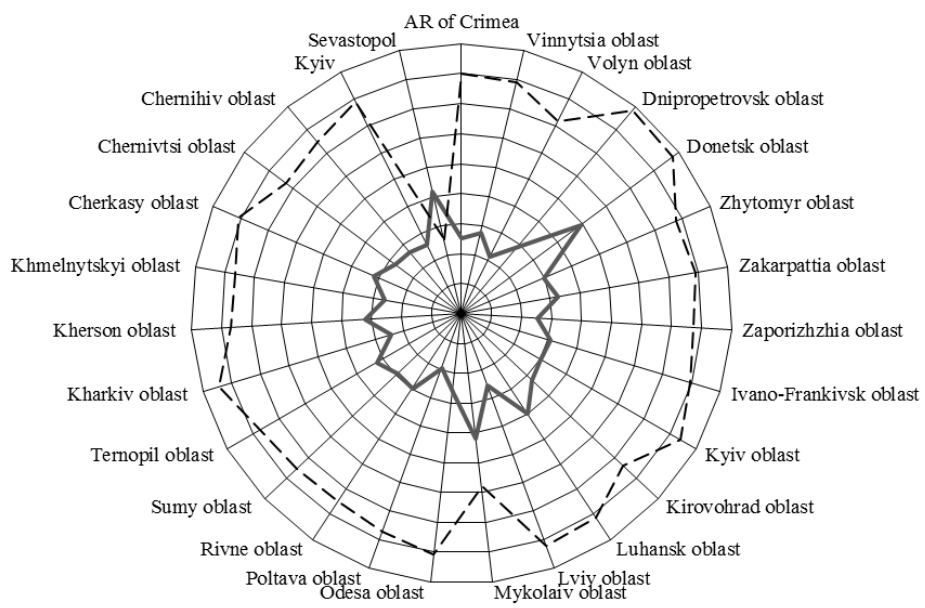

- Valid economic potential

- - - Normative economic potential

Fig. 4. The graphic model of the "distance" of the real economic potential of the average capital repairs value ( $Z P k r$ dis) from the normative one in the regions of Ukraine.

To reach the calculated normative demand in the market multiple dwelling housing and cottages for the economy class if there is such a need in this segment can be possible only in 11 years, European indicators - in 19 years (Figure 5).

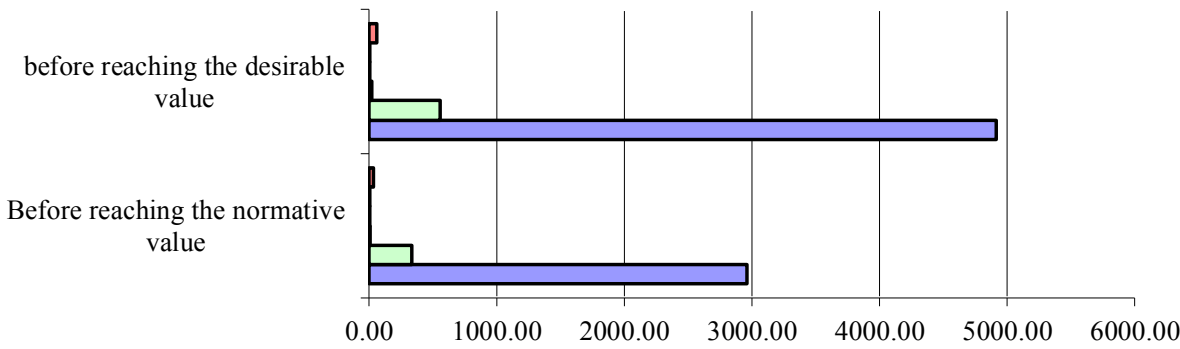

Before reaching the normative value

口New housing 36.8

口Countryside housing 0.8

口Elite class housing 0.5 1.

口Market multiple dwelling housing and cottages of economy class

\section{$\square$ Social housing}

口Available housing

$11.4 \quad 18.8$

0.8

Fig. 5. The duration of reaching normative and desirable housing provisions, years.

The worst situation is observed in the segment of new building of available and social housing where the demand can be reached in 336-4913 years at the existing tempos of taking housing into use. Thus, it is crucial to pay the greatest attention to those segments while developing the directions of the state housing policy. 


\section{Conclusions and recommendations}

Multifactor multiplicative model built with the coefficients identified allows to forecast the distance change of the real economic potential from the normative and the desired ones in the regions due to the impact factors change on the housing economic potential level.

It's worth to carry out the analyses of the graphic model built on the similarity of the polygons received. The similarity signifies of the fact that impact factor weights on the real economic potential are similar to the weights of the impact factors or on the normative (in Ukraine) potential, or similar to the weights of the impact factors on the desired (European) potential. Thus, disproportions in the regions of Ukraine in this economic potential are absent. That's why managerial and financial economic actions are directed to the approach of the real economic potential to the normative one in the regions, but they should account for the weights of the impact factor and shouldn't lead to their considerable change. If there is no similarity between the polygons, managerial actions should lead the weights of the impact factors to the values of these factors weights which have space for the normative potential. Only after the disproportion in regions development is eliminated it is possible to bring the adjusted weights to their normative values.

\section{References}

1. A.I. Amosha, V.G. Sievka, E.V. Shelikhova, N.B. Paliga, Anti-crisis state policy in the construction industry: mechanisms of realization 242 (2010)

2. Beer Stafford Diagnosing the system for organizations: The managerial cybernetics of organization (1998)

3. S.A. Bolotin, A.Kh. Dadar, I.S. Ptukhina, Magazine of Civil Engineering 7, 82-86 (2011)

4. S. Bolotin, A. Dadar, I. Ptuhina, Advanced materials research 945-949, 3026-3021 (2014)

5. J. Curwin, R. Slater, Quantitativ methods for business decisions (International Thomson Business Press, London etc., 1997)

6. E. Ganebnykh, T. Burtseva, A. Petuhova, A. Mottaeva, E3S Web of Conferences 91, 08035 (2019) doi.org/10.1051/e3sconf /20199108035

7. Floor area: Glossary of statistical terms, http://stats.oecd.org/glossary/detail.asp?ID=1004.

8. R.A. Grafton, Quentin, Sargent, C. Timoth, Workbook in mathematical method for economists (1998)

9. Housing code of Ukrainian SSR № 5464-X (1983) http://zakon1.rada.gov.ua/

10. Housing statistics, http://epp.eurostat.ec.europa.eu/statistics explained/index.php/Housing_statistics

11. Housing statistics in the European. Research Institute for the Built Environment at Delft University of Technology (Ministry of the Interior and Kingdom Relations, The Hague, 2010)

12. D. Isayenko, Public administration: theory and practice 3(7), 146-151 (2011)

13. O.A. Karlova, Bulletin of East-Ukrainian national University named after Volodymyr Dahl 2.16(205), 111- 116 (2013)

14. Yu.M. Mantsevich, Social and economic problems of housing development and strategy of development: monograph (2007) 
15. Yu.V. Orlovska, Economics of construction and urban development 10(1), 5-11 (2014)

16. I.S. Ptukhina, Polythematic network electronic scientific journal of the Kuban state agrarian University 68, 188-189 (2011)

17. Ragnar Frisch, Economic Essays in Honor of Gustav Casse, 12-17 (1933)

18. V.G. Sievka, V.V. Khrapkina, Scientific-theoretical and practical journal. Series: economic science, public administration 30(78), 42-50 (2013)

19. The statistical Bulletin "Housing and the number of provided apartments in Ukraine in 2012”. State statistics service of Ukraine (2013)

20. The statistical Bulletin "Acceptance into operation of housing in Ukraine in 2012". The State statistics service of Ukraine (2013)

21. The statistical Bulletin "The state of the buildings and facilities of unfinished construction in Ukraine. State statistics service of Ukraine (2013)

22. The statistical publication "Regions of Ukraine 2012". The State statistics service of Ukraine (2012)

23. The order of the State Committee of construction, architecture and housing policy of Ukraine "On approval of the Single classification of residential buildings depending on the quality of available housing and engineering equipment", zakon.nau.ua/doc/?uid=1041.2862.0

24. Official Herald of Ukraine 800-V(9), 257 (2009)

25. Official Herald of Ukraine 2929/227(4), 238 (2005)

26. The order of the Russian Federation "On approval of the Instruction on carrying out accounting of the housing Fund in the Russian Federation" from 4.08.1998, www.consultant.ru/document/cons_doc_LAW-77193/

27. Worldwide quality-of-life index, http://www.economist.com 